\title{
Using stylet elemental signatures to determine the population structure of Octopus maorum
}

\author{
Zoë A. Doubleday ${ }^{1, *}$, Gretta T. Pecl ${ }^{1}$, Jayson M. Semmens ${ }^{1}$, Leonid Danyushevsky ${ }^{2}$ \\ ${ }^{1}$ Marine Research Laboratories, Tasmanian Aquaculture \& Fisheries Institute, Private Bag 49, and \\ ${ }^{2}$ Centre for Ore Deposit Research, Private Bag 79, University of Tasmania, Hobart, Tasmania 7001, Australia
}

\begin{abstract}
A novel method was used to investigate the population structure and dispersal patterns of Octopus maorum, an octopus species with a planktonic larval stage, which forms a distinct and large aggregation in southeast Tasmania. Single and multi-elemental signatures within the 'early life history' region of the stylet (an internal 'shell') were used to determine levels of connectivity and the common origins of individuals collected from 5 locations across Tasmania, South Australia and New Zealand. Using laser ablation inductively coupled plasma-mass spectrometry (LA ICPMS) the stylets were analysed for 12 elements, 8 of which were found to be excellent spatial discriminators. There was evidence of population structuring within the $O$. maorum population, with a distinct separation of the aggregation site in southeast Tasmania from other groups. Octopuses from the aggregation shared a common origin and appeared to be coming from a local neighbouring source. The 2 northern sample locations shared a similar elemental signature, which could be due to either similar water chemistries or long-distance dispersal. This study presents the first insights into the population structure of $O$. maorum, and provides vital information for the sustainable management of this species. Furthermore, this technique will have direct application to other more heavily fished octopus species around the world.
\end{abstract}

KEY WORDS: Population structure · Octopus $\cdot$ Laser ablation $\cdot$ Stylets $\cdot$ Dispersal $\cdot$ Octopus maorum

\section{INTRODUCTION}

It is generally assumed that species with planktonic larvae have a comparatively reduced population structure or are highly connected, as it is possible to achieve a thorough mixing of long-distance individuals from different source populations (Avise 2004, Becker et al. 2007). However, many species with planktonic larvae exhibit limited dispersal and localised subpopulations that are relatively independent of each other (see Avise 2004, Palumbi 2004 for examples). Understanding the level of connectivity and structure within a population is vital for understanding baseline biology, determining the resilience of populations to harvesting and defining the appropriate scale at which a fishery ought to be managed, thus helping to develop sustainable management strategies (Thorrold et al. 2001, Gillanders 2002).
In spite of the ecological importance and increasing commercial significance of octopuses on a global scale, little is known about the population structure or dispersal patterns of most octopus species or indeed cephalopods in general. Only a handful of studies investigating these aspects of octopus populations have been conducted (e.g. Maltagliati et al. 2002, Oosthuizen et al. 2004), and are restricted to only 1 species (Octopus vulgaris). O. maorum is a large (growing up to $15 \mathrm{~kg}$ ) species which is common throughout southern Australian and New Zealand temperate and subantarctic coastal waters (Stranks 1996). O. maorum is 'merobenthic', producing hatchlings or paralarvae that are planktonic before they settle to the seafloor and adopt the adult benthic lifestyle. Of particular interest is a large (1000s of individuals) year-round aggregation of mature $O$. maorum in Eaglehawk Bay, southeast Tasmania, Australia, which 
also supplies small but intensive recreational and commercial fisheries. The reason for the aggregation and the source of the animals remain unknown, and despite the vast majority of individuals being fully mature, there is no evidence of spawning. Virtually nothing is known about the population structure and dispersal patterns of $O$. maorum, which is also true for many other commercial merobenthic species, including Enteroctopus dofleini (Rigby \& Sakurai 2005), O. mimus (Rocha \& Vega 2003) and O. vulgaris (Balguerías et al. 2000).

The quantitative and spatial distributions of trace chemical elements within the hard biomineralised structures of marine organisms are influenced by their availability in the seawater, and commonly reflect changes in the chemical, physical and biological environment. Biomineralised structures with a temporally related incremental structure may incorporate elements chronologically, providing a natural 'tag' that reflects an individual's movement history (Elsdon \& Gillanders 2005). The environmental time-recording properties of such natural tags can be exploited using microprobe analysis, particularly laser ablation inductively coupled plasma-mass spectrometry (LA ICPMS), which allows microstructural regions of interest to be specifically targeted and their elemental 'signature' analysed. Targeted microanalytical techniques have been employed extensively on fish otoliths (Campana 1999), and also on gastropod shells (Zacherl 2005), bivalve shells (Becker et al. 2005) and squid statoliths (Zumholz et al. 2007), providing information on the population structure, recruitment processes and dispersal patterns of many species. To determine the natal origins of adults and dispersal trajectories of juveniles, it is ideal to directly compare the elemental chemistry of juvenile hard structures to the pre-hatch region of the adult structure (e.g. Hamer et al. 2005); however, this method is not suitable for all species. Octopus maorum hatchlings, for example, are only $5 \mathrm{~mm}$ long, making it virtually impossible to successfully prepare and analyse hatchling stylets using microprobe techniques. However, when juveniles are difficult to obtain or process, adult elemental signatures alone can provide information on common origins and level of connectivity between geographically disparate groups within a population (e.g. Ashford et al. 2006, Swan et al. 2006).

Although studies based on the targeted elemental analysis of cephalopod hard structures are few, this has been shown to be a useful technique in examining the population structure and movement patterns of squid (Zumholz et al. 2007). The paucity of elemental studies on octopuses may be partly due to the lack of age-related growth increments in octopus statoliths. However, stylets, a structure unique to Octopoda, have been found to have a visible pre-hatch region and agerelated concentric growth in the form of daily increments (Doubleday et al. 2006). Stylets consist of a pair of fine shell-like rods embedded within the mantle musculature (Bizikov 2004), and although they have a predominantly organic structure (rather than $\mathrm{CaCO}_{3}$ ), research has shown that the inner and more calcified portion of the stylet should be suitable for LA analysis (Doubleday et al. 2007).

The present study is the first time stylet elemental signatures have been used to examine the structure and dispersal patterns of an octopus population. The following key questions were investigated: (1) Are elemental signatures from the 'early life history' region of the stylet useful spatial discriminators? (2) Is there a level of connectivity between geographically isolated individuals? (3) Do individuals from the same location share a common origin or come from a range of locations?

\section{MATERIALS AND METHODS}

Stylet collection and preparation. Octopuses were collected from 5 sites: northeast Tasmania (NE), southwest Tasmania (SW), the Eaglehawk Bay aggregation (EHB) in southeast Tasmania, South Australia (SA) and New Zealand (NZ) (Fig. 1). Octopuses were collected as bycatch from rock lobster fishers (at depths between 10 and $40 \mathrm{~m}$ ) from all sites except EHB, where they were collected from the commercial octopus fishery (at depths between 1 and $3 \mathrm{~m}$ ). All specimens were frozen prior to dissection. Whole wet weight $(\mathrm{kg})$ or mantle weight $(\mathrm{g})$ (as the arms were often removed), sex and stage of maturity were recorded. Males were classed as mature or immature, depending on the presence or absence of visible spermatophores in Needham's sac. Females were assigned a maturity stage from 1 to 3 (immature, maturing or mature) depending on ovary size and level of egg development (Smith et al. 2006). Octopuses ranged in size from 0.7 to $10.2 \mathrm{~kg}$. All males and $50 \%$ of females were mature.

Stylets were removed from thawed mantle tissue (see Bizikov 2004 for stylet location) and allowed to air dry for $2 \mathrm{~d}$ prior to being stored dry. Transverse sections, $\sim 3 \mathrm{~mm}$ thick, were cut from the post-rostral zone proximal to the bend (Fig. 2). The stylet sections were placed vertically onto double-sided tape and then surrounded by a thin layer of epoxy, which was left to partially set for $10 \mathrm{~min}$ before pouring on the remaining epoxy and drying them in an oven for $3 \mathrm{~h}$ at $60^{\circ} \mathrm{C}$. Once set, the mounts were ground using 1200 grit carborundum paper lubricated with ultra-pure water until all cross-sections were exposed, and then polished using $0.3 \mu \mathrm{m}$ alumina powder on a pellon 

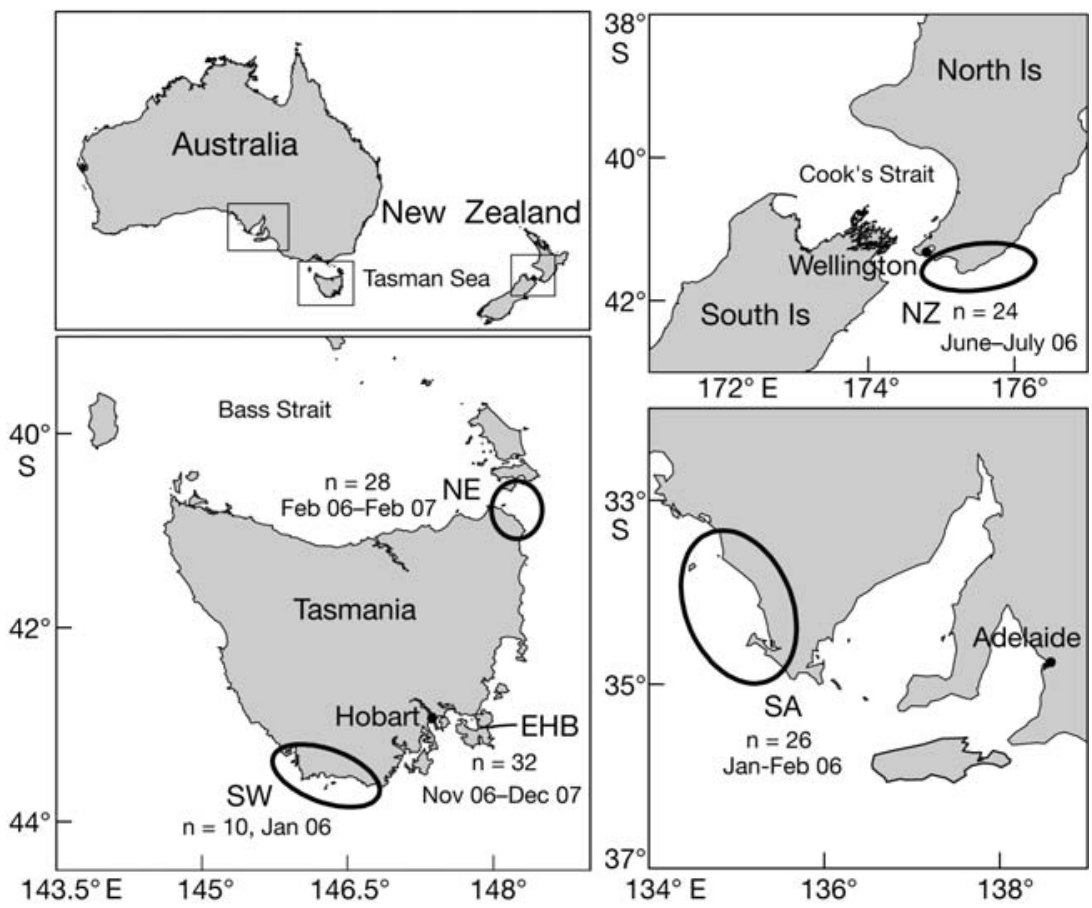

Fig. 1. Octopus maorum. Sample locations, sample sizes (n) and collection dates. Sites: South Australia (SA), northeast Tasmania (NE), New Zealand (NZ), southwest Tasmania (SW) and the Eaglehawk Bay aggregation (EHB)
Research (CODES), University of Tasmania. The New Wave UP-193 Nd:YAG Q-switched LA system was connected to an Agilent HP7500cs Quadrapole ICPMS and controlled by the MEOLaser 193 software package. For each sample, a single spot ablation was performed, which targeted a distinct early life history region within the central region of the stylet crosssection (Fig. 2). The concentric agerelated growth of the stylets implies that this inner region of the stylet represents the earliest stages of the life cycle; however, the approximate size of the pre-hatch region has not been validated in the stylet microstructure of Octopus maorum. Furthermore, if a reasonable spot size and detection limits (DL) are to be maintained, the pre-hatch region alone would be too small to target, as the width of $1 \mathrm{~d}$ old stylets, and thus the pre-hatch region within the adult stylet, would be $<10 \mu \mathrm{m}$. A $35 \mu \mathrm{m}$ ablation spot size was used, which covered $\sim 3 \%$ of the whole stylet cross-section. Based on

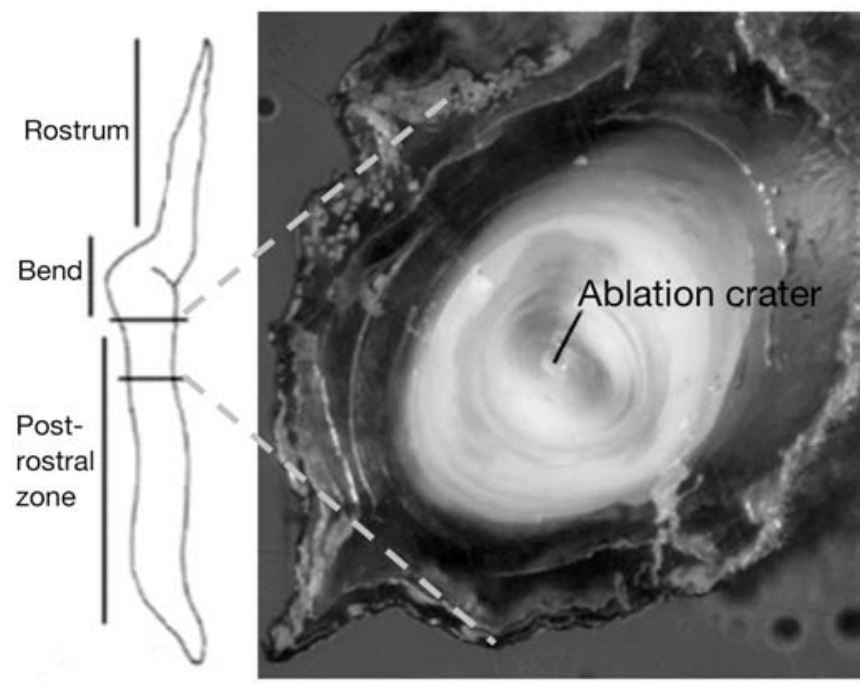

Fig. 2. Octopus maorum. Location of elemental analysis within the stylet structure shown by the ablation crater (the result of a $35 \mu \mathrm{m}$ spot ablation). The image is a stylet cross-section ( $\times 63$ magnification) mounted in epoxy, which has been removed from the post-rostral zone (indicated by solid horizontal lines in the diagram)

cloth polishing disc. The mounts were rinsed thoroughly in ultra-pure water and allowed to air dry.

Analytical methods. Elemental analyses were performed using LA ICPMS at the Centre for Ore Deposit
O. maorum age data ( $\mathrm{J}$. White unpubl. data), it is estimated that a $35 \mu \mathrm{m}$ spot size would approximately incorporate the first $7 \mathrm{~d}$ of an individual's life.

LA was performed with a laser pulse rate of $10 \mathrm{~Hz}$ and average laser energy of 4 to $5 \mathrm{~J} \mathrm{~cm}^{-2}$. To remove surface contamination, each sample was pre-ablated at $1 \mathrm{~Hz}$ for $5 \mathrm{~s}$ prior to analysis. Background levels were measured for $30 \mathrm{~s}$ prior to each ablation, the average of which was subtracted from the subsequent sample analysis to correct for background levels. Due to the lack of matrix-matched standards, the international glass reference National Institute of Standards and Technology (NIST) 612 was used as the external standard (Pearce et al.). Although relying solely on NIST standards results in reduced analytical accuracy in terms of absolute values, good analytical precision should allow valid comparisons between relative differences in elemental concentrations (e.g. Zumholz et al. 2007). To account for instrument drift throughout the analyses, the NIST standard was ablated twice every $90 \mathrm{~min}$. The following suite of 12 elements was recorded for each analysis: ${ }^{7} \mathrm{Li},{ }^{24} \mathrm{Mg},{ }^{55} \mathrm{Mn},{ }^{59} \mathrm{Co},{ }^{60} \mathrm{Ni}$, ${ }^{65} \mathrm{Cu},{ }^{208} \mathrm{~Pb},{ }^{66} \mathrm{Zn},{ }^{75} \mathrm{As},{ }^{85} \mathrm{Rb},{ }^{88} \mathrm{Sr}$ and ${ }^{137} \mathrm{Ba}$. To correct for variations in ablation yield, ${ }^{43} \mathrm{Ca}$, set at a constant $13 \%$, was used as the internal standard. Calcium was chosen as the internal standard due to its consistent concentration and homogeneous distribution within the inner region of the stylet (see Doubleday et al. 2007). 
Data reduction was performed offline using spreadsheet programs. The DLs for each element were calculated from the concentration of analyte that yields a signal equivalent to 3 times the SE of the background signal. The mean DLs for a $35 \mu \mathrm{m}$ spot size were (in ppm): Li, 0.033; Mg, 0.273; Mn, 0.093; Co, 0.013; Cd, 0.100; $\mathrm{Ni}, 0.059 ; \mathrm{Cu}, 0.071 ; \mathrm{Pb}, 0.009 ; \mathrm{Zn}, 0.133$; As, 0.203; Rb, 0.010; Sr, 0.068; and Ba, 0.026. All elements except $\mathrm{Co}$ and $\mathrm{Pb}$ were consistently above DLs. Although $\mathrm{Co}$ and $\mathrm{Pb}$ were below DLs in 10 and $15 \%$ of the samples respectively, $93.5 \%$ of those samples were restricted to 2 sites (SA and NE). Due to such concentration differences between sites, $\mathrm{Co}$ and $\mathrm{Pb}$ were retained in the analyses. One method to deal with values generated when an element falls below DLs is to substitute them with a constant, such as one-half of the DL (recommended by Farnham et al. 2002). Statistical analyses were performed using both the original values and substituted values based on one-half of the DL (0.0045 for $\mathrm{Pb}$ and 0.0065 for $\mathrm{Co}$ ); however, the results were the same.

Statistical analyses. To determine differences in elemental concentrations among sites for individual elements, 1-way ANOVA was performed. Elemental data were examined for normality and homogeneity of the variances using graphical methods and Levene's test. To meet model assumptions, Li, Cu, Zn, Mn, Mg and $\mathrm{Ni}$ were $\log _{10}(y+1)$-transformed, $\mathrm{Pb}$ and Co were $\log _{10}(y+2.5)$-transformed, and As was $y^{-0.5}$-transformed. All a posteriori comparisons among sites were conducted using Tukey's HSD test $(\mathrm{p}<0.05)$. To test for differences between sexes and between sex and site, a separate 2-way factorial ANOVA was performed for each element using animals from all sites $(n=120)$.

Elements which showed significant differences among sites in the univariate analyses were used for the multivariate analysis $(n=10)$. To determine the most important elements for the discrimination of sites, forward stepwise discriminant function analysis (DFA) was performed. This also served to reduce the number of dependent variables. All elements except $\mathrm{Ni}$ and $\mathrm{Rb}$ significantly contributed to the discrimination of sites. A second DFA was performed with these 2 elements removed. Differences in elemental concentrations between sites for multi-elemental signatures $(n=8)$ were determined using 1-way multivariate ANOVA (MANOVA). Pillai's trace was used as the test statistic. Canonical discriminant plots were used to visualise multivariate differences in elemental signatures among sites. To assess how accurately individuals could be assigned to site using multi-elemental signatures, cross-validation classifications were performed using jackknife 'leave one out' procedures. To compare the relative individual variability among sites, scatterplots of elemental concentration and site were constructed using untransformed data (4 of the elements are presented). Cross-validation was performed using SPSS (v. 13) and all other analyses were performed using STATISTICA (v. 8, StatSoft).

\section{RESULTS}

All single elemental signatures detected within the stylets were significantly different among sites, except for $\mathrm{Cu}$ and $\mathrm{Zn}$, with $\mathrm{Mg}$, $\mathrm{As}, \mathrm{Co}, \mathrm{Pb}, \mathrm{Mn}$ and Ba showing highly significant differences $(p<0.001)$ (Table 1). $\mathrm{Li}, \mathrm{Rb}$ and $\mathrm{Ni}$ discriminated among sites the least, and $\mathrm{Mn}$ and $\mathrm{Pb}$ the most (Table 2). Each site significantly differed from each other site by 3 to 4 elements, except for SA/NE and NZ/SW, which both only differed by 2 elements. There were few similar among-site trends

Table 1. Octopus maorum. One-way ANOVA comparing elemental concentrations among sites in the 'early life history' region of the stylets. Elemental concentrations were transformed as described in 'Materials and methods'

\begin{tabular}{|c|c|c|c|c|}
\hline Source & $\mathrm{df}$ & MS & $F$ & $\mathrm{p}$ \\
\hline \multicolumn{5}{|l|}{$\mathbf{L i}$} \\
\hline Site & 4 & 0.05 & 2.55 & 0.042 \\
\hline Error & 115 & 0.02 & & \\
\hline \multicolumn{5}{|l|}{ Ba } \\
\hline Site & 4 & 198.24 & 6.28 & 0.001 \\
\hline Error & 115 & 31.59 & & \\
\hline \multicolumn{5}{|l|}{$\mathrm{Sr}$} \\
\hline Site & 4 & 1.7 & 3.75 & 0.006 \\
\hline Error & 115 & 4.56 & & \\
\hline \multicolumn{5}{|l|}{$\mathrm{Cu}$} \\
\hline Site & 4 & 0.1 & 2.38 & 0.056 \\
\hline Error & 115 & 0.05 & & \\
\hline \multicolumn{5}{|l|}{ Zn } \\
\hline Site & 4 & 0.12 & 2.13 & 0.081 \\
\hline Error & 115 & 0.04 & & \\
\hline \multicolumn{5}{|l|}{$\mathbf{R b}$} \\
\hline Site & 4 & 1.85 & 2.81 & 0.027 \\
\hline Error & 115 & 0.65 & & \\
\hline \multicolumn{5}{|l|}{ Mg } \\
\hline Site & 4 & 0.06 & 34 & 0.001 \\
\hline Error & 115 & 0 & & \\
\hline \multicolumn{5}{|l|}{ Mn } \\
\hline Site & 4 & 3.37 & 101.69 & 0.001 \\
\hline Error & 115 & 0.02 & & \\
\hline \multicolumn{5}{|l|}{ As } \\
\hline Site & 4 & 54.79 & 9.9 & 0.001 \\
\hline Error & 115 & 5.53 & & \\
\hline \multicolumn{5}{|l|}{$\mathrm{Ni}$} \\
\hline Site & 4 & 0.15 & 2.73 & 0.032 \\
\hline Error & 115 & 0.06 & & \\
\hline \multicolumn{5}{|l|}{$\mathrm{Pb}$} \\
\hline Site & 4 & 15.93 & 96.77 & 0.001 \\
\hline Error & 115 & 0.16 & & \\
\hline \multicolumn{5}{|l|}{ Co } \\
\hline Site & 4 & 3.88 & 33.45 & 0.001 \\
\hline Error & 115 & 0.11 & & \\
\hline
\end{tabular}


between elements, except for $\mathrm{Sr}$ and $\mathrm{Rb}$, which showed a striking similarity in relative concentrations. Prominent among-site differences for individual elements included high levels of As in EHB, high levels of Ba in SA and NZ, low levels of Mg in SA and low levels of $\mathrm{Co}$ and $\mathrm{Pb}$ in $\mathrm{SA}$ and $\mathrm{NE}$. Individual variability in elemental concentration was relatively similar for $\mathrm{Sr}, \mathrm{Mg}$ and $\mathrm{Ba}$ between sites. $\mathrm{Mn}, \mathrm{Co}, \mathrm{Pb}$ and As showed a larger range in concentration, which was particularly evident in the $\mathrm{EHB}$ site for $\mathrm{Pb}$ and $\mathrm{As}$ (Fig. 3).

Multi-elemental signatures were highly significant among sites (MANOVA: Pillai's trace $\left.=1.92, F_{28,448}=14.9, \mathrm{p}<0.001\right)$. All elements, except $\mathrm{Ni}$ and $\mathrm{Rb}$, significantly contributed to the discrimination among sites (stepwise DFA: $F>2.5, \mathrm{p}<0.05$ ). Discriminant functions 1 and 2 explained 78 and $11 \%$ of the variation, respectively. Overall, $\mathrm{Pb}$ contributed the most variation among sites, followed by Mn and Sr, while Li contributed the least (Table 3). EHB had the most distinct signature, which was separated from the other sites largely by differences in $\mathrm{Pb}, \mathrm{Mn}$ and As concentrations (Fig. 4). Although NZ shares some overlap with $\mathrm{SW}$ and $\mathrm{SE}$, it showed some separation, particularly from $\mathrm{Co}, \mathrm{Mn}$ and $\mathrm{Mg}$, described by discriminant function 2 . SA and NE shared the most similar multi-elemental signature, which was separated from the remaining sites largely by Sr. The overall cross-validated classification rate was $91.7 \%$, based on the 8 elements entered in the final DFA (Table 4). Most misclassifications were associated with SA and NZ, which had 19.2 and $12.5 \%$ of their individuals misclassi-
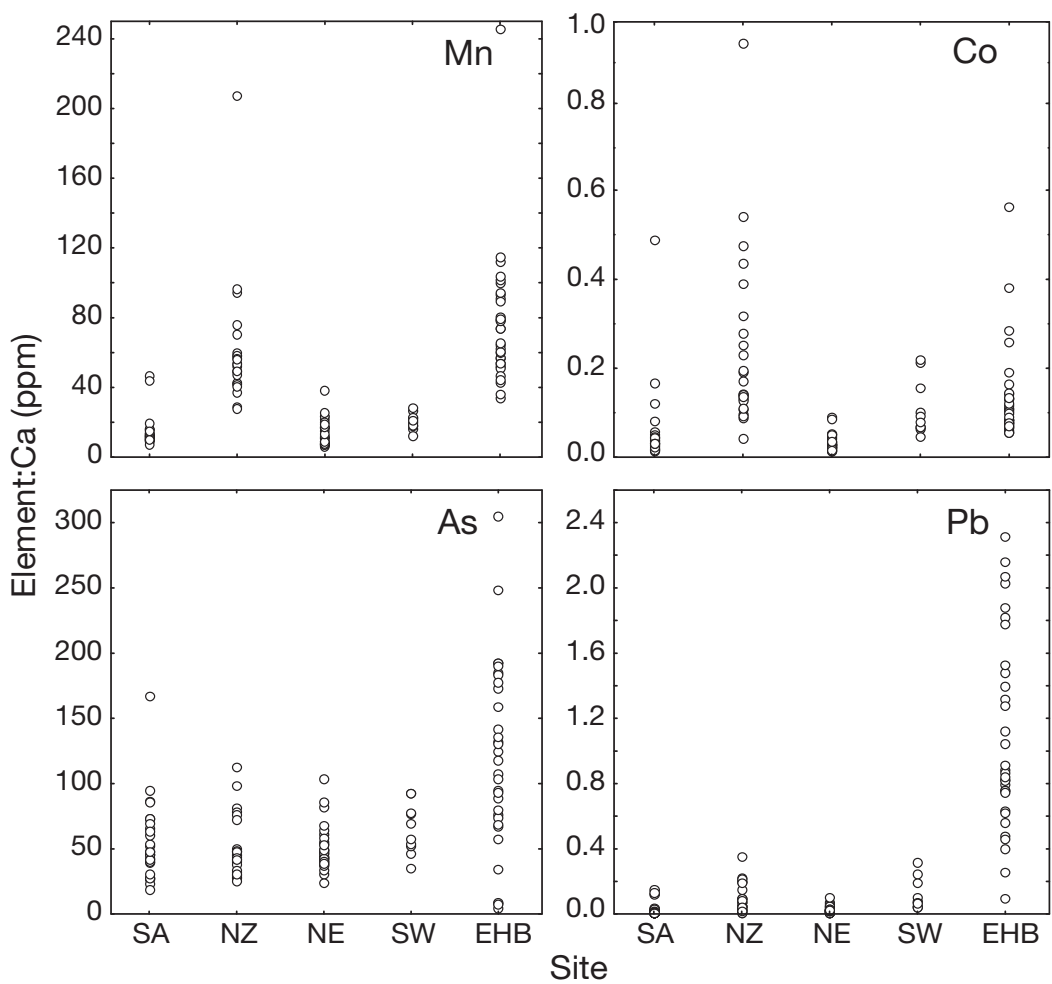

Fig. 3. Octopus maorum. Individual variability in $\mathrm{As}, \mathrm{Co}, \mathrm{Mn}$ and $\mathrm{Pb}$ concentrations for each site. Each circle represents an individual octopus. SA: South Australia; NZ: New Zealand; NE: northeast Tasmania; SW: southwest Tasmania; EHB: Eaglehawk Bay

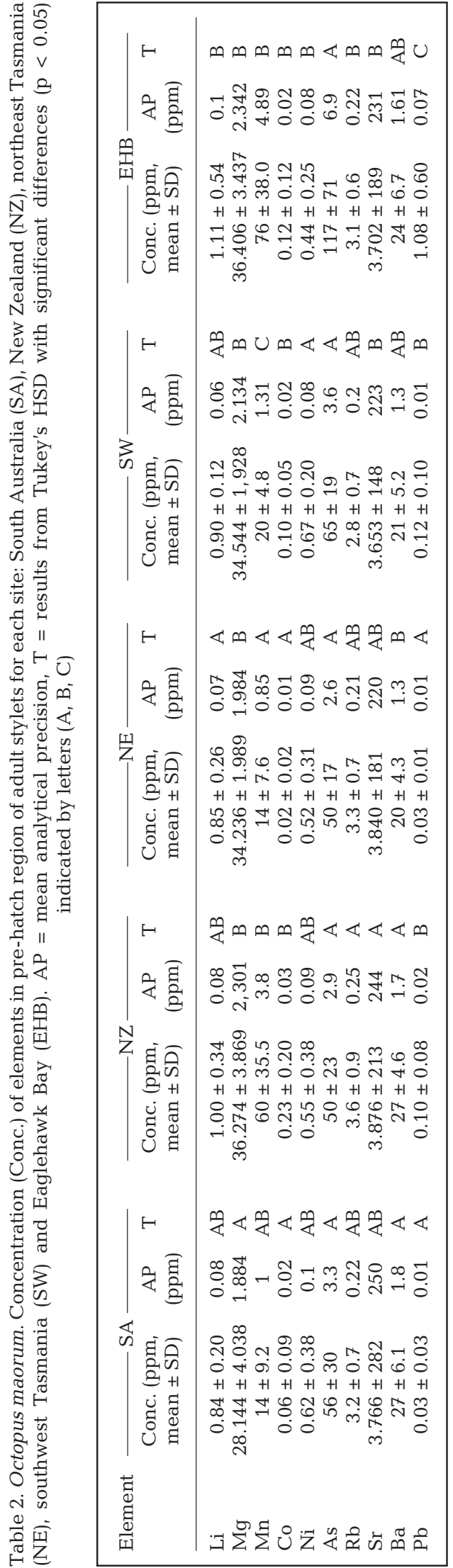


Table 3. Standardised canonical coefficients for discriminant functions (DF) 1 and 2 for each element entered in the final DFA. Coefficients represent the relative contribution of each element to each DF

\begin{tabular}{|lrr|}
\hline Element & DF1 & DF2 \\
\hline $\mathrm{Mn}$ & -0.69 & -0.43 \\
$\mathrm{~Pb}$ & -0.74 & 0.64 \\
$\mathrm{Mg}$ & -0.40 & -0.40 \\
$\mathrm{Sr}$ & 0.61 & -0.16 \\
$\mathrm{Co}$ & -0.02 & -0.62 \\
$\mathrm{Ba}$ & 0.35 & -0.06 \\
$\mathrm{As}$ & -0.23 & 0.63 \\
$\mathrm{Li}$ & 0.07 & 0.37 \\
\hline
\end{tabular}

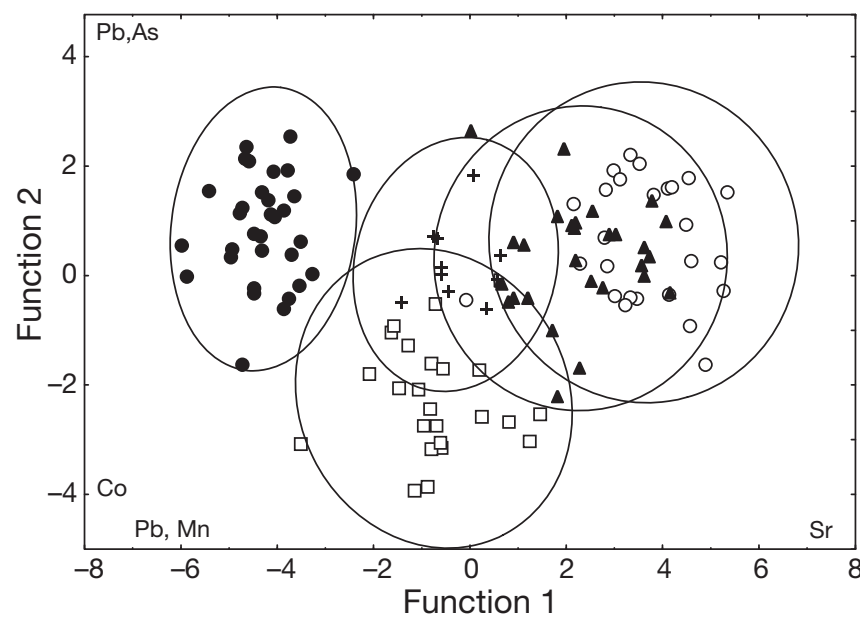

Fig. 4. Canonical discriminant plots comparing multi-elemental signatures among sites. Elements that contributed most variation to the data (canonical coefficients) are indicated at both ends of each axis. Ellipses represent $95 \%$ CIs around the centroids of each group. Sites: South Australia (O), Eaglehawk Bay (@), New Zealand ( $\square)$, northeast Tasmania $(\mathbf{\Delta})$ and south west Tasmania (+)

Table 4. Predicted group memberships from cross-validation classification procedures for each site, based on DFA scores from multi-element data. Results indicate the percentage of individuals classified to each site, with correct classifications in bold. Sites: South Australia (SA), New Zealand (NZ), northeast Tasmania (NE), southwest Tasmania (SW) and Eaglehawk Bay (EHB)

\begin{tabular}{|lccccc|}
\hline Site & SA & NZ & NE & SW & EHB \\
\hline SA & $\mathbf{8 1}$ & 3.8 & 15 & 0 & 0 \\
NZ & 0 & $\mathbf{8 8}$ & 4.2 & 8.3 & 0 \\
NE & 0 & 3.6 & $\mathbf{9 3}$ & 3.6 & 0 \\
SW & 0 & 0 & 0 & $\mathbf{1 0 0}$ & 0 \\
EHB & 0 & 0 & 0 & 0 & $\mathbf{1 0 0}$ \\
\hline
\end{tabular}

fied respectively. Four out of 5 misclassified individuals from SA were classified as NE individuals. The most distinct sites were SW and EHB, with $100 \%$ of individuals being correctly classified.
There was no significant effect of sex on elemental concentration for all elements, except for $\mathrm{Ni}$ and $\mathrm{Co}$ (2-way ANOVA: Co, df $=1, F=9.19, \mathrm{p}=0.003 ; \mathrm{Ni}$, $\mathrm{df}=1, F=5.19, \mathrm{p}=0.025$ ), with females having a significantly lower concentration than males. However, site-sex interaction effects were not significant for $\mathrm{Ni}$ or Co (2-way ANOVA: Co, $\mathrm{df}=4, F=0.42, \mathrm{p}=0.78$; Ni, $\mathrm{df}=4, F=1.08, \mathrm{p}=0.35)$.

\section{DISCUSSION}

Single and multi-elemental signatures within the early life history region of stylets were informative spatial discriminators for Octopus maorum. The discrimination of elemental signatures between sampling sites suggests that elemental concentrations in the early life history region probably reflect the environment the individuals inhabited at that time in their life history, and thus can act as a proxy for octopus dispersal. The elemental signatures indicate a level of structuring within the O. maorum population. The presence of structure challenges the common assumption that populations with planktonic larval stages are relatively unstructured. Although the duration of the planktonic larval stage in O. maorum is not known, it is likely that other factors influence its dispersal. Population structuring observed in other cephalopods with planktonic larvae, including O. vulgaris (Murphy et al. 2002, Teske et al. 2007), Loligo gahi (Arkhipkin et al. 2004) and Todaropsis eblanae (Dillane et al. 2005), has been suggested to be caused by oceanographic conditions and historic climatic events.

The multivariate analyses suggest that individuals from the EHB aggregation have a common natal origin, and are separated predominantly from the northern populations. It is assumed that individuals aggregating in EHB as adults have hatched elsewhere, due to the scarcity of hard substrate for the attachment of egg broods within the bay, the dominance of particularly large mature animals in the fishery catch for $17 \mathrm{yr}$ and no known observations of juveniles or egg broods. Although the natal origin of the EHB individuals is speculative, the elevated levels of $\mathrm{Pb}$ and As suggest that they hatched in coastal waters comparatively close to the industrialised Derwent estuary. Pollution has resulted in significantly elevated levels of $\mathrm{Pb}$ and $\mathrm{As}$ in the Derwent estuary, compared to surrounding waters (Jones et al. 2003), making the southeast region comparatively heterogeneous in elemental distributions. If the aggregating animals are hatching within this region, it would explain the very broad range of As and $\mathrm{Pb}$ (and potentially $\mathrm{Co}$ and $\mathrm{Mn}$ ) levels between the individuals from EHB. Furthermore, all other sites are relatively exposed and isolated from industrial pollu- 
tion, suggesting that individuals from the aggregation are not hatching in such environments. In light of this, the Octopus maorum fishery at EHB should be managed as a separate stock, as replenishment from neighbouring sources may be limited.

SA and NE share a relatively similar elemental signature, with only 2 elements being significantly different between the 2 sites, resulting in the misclassification of some individuals. Such similarities could be due to long-distance dispersal (some individuals may share a common origin or undergo post-hatch mixing), or the 2 sites having similar water chemistries. Oceanic currents within the region support the possibility of such dispersal patterns: the Leeuwin current flows eastward along the south coast of Australia, which then flows southward (turning into the Zeehan current) along the west coast of Tasmania (Crawford et al. 2000), while pushing water eastward across Bass Strait (Tomczak 1981). There is no evidence to suggest that there is a regular exchange of individuals between Australia and NZ. The elemental signature from NZ is distinct from Australian signatures, with particularly high levels of Co. The possibility of trans-Tasman dispersal should not be ruled out, however, as not all key regions within the distribution of Octopus maorum were sampled (e.g. Victoria and the west coast of NZ). Furthermore, a small percentage of individuals from NZ were classified as Tasmanian and vice versa for Tasmanian individuals, which is supported by the scatterplots of Mn and Co (key elements which separated NZ from the other sites), which show some individuals not fitting the general trend.

Time-specific micro-chemical studies are based on the assumption that the structure grows throughout the life cycle of the organism and is metabolically inert or undergoes no post-depositional modification (Campana 1999). Although it has been shown that stylets undergo temporally related incremental growth (Doubleday et al. 2006), it is not known whether stylet material is reworked over time (in other words, the elemental signature may not reflect the environment to which the individual was exposed). However, the large suite of elements that were found to be useful spatial discriminators suggests that they are relatively stable once incorporated into the structure. Elemental incorporation into the stylet structure may also be under differing degrees of physiological control. Of the elements detected within the stylets, 8 are classified as essential for cephalopod function (Mn, Mg, Sr, Co, Ni, Zn, Cu and $\mathrm{Rb}$ ) (Villanueva \& Bustamante 2006) and are likely to be under some level of internal regulation. However, 4 of these essential elements ( $\mathrm{Mn}, \mathrm{Mg}, \mathrm{Sr}$ and $\mathrm{Co}$ ) were excellent spatial discriminators in the present study, suggesting that environmental availability exerts a greater effect on stylet composition than physiology.
Although Co and Ni were significantly higher in males, suggesting that concentration is controlled somewhat by physiological processes, the effect of geographical location outweighed the effect of sex. The lack of differentiation in $\mathrm{Cu}$ and $\mathrm{Zn}$ concentrations among sites indicates that these elements are either predominantly under physiological control or are just similar between sites. However, 2 studies suggest that $\mathrm{Cu}$ and $\mathrm{Zn}$ are largely under metabolic control in Octopus vulgaris, in the muscle tissue of adults (Raimundo et al. 2004) and in eggs (Villanueva \& Bustamante 2006). Even though the mechanistic controls of elemental incorporation in stylets is not understood, and physiology could have some effect on elemental incorporation, consistent geographical patterns in elemental signatures can be exploited as natural tags regardless of whether the signature was governed directly by water chemistry or a complex interaction of environment, physiology and behaviour (Gillanders 2005, Swan et al. 2006).

There have been relatively few studies on the direct causal and regulatory mechanisms that govern the incorporation of elements into biomineralised structures. Ba (Zacherl et al. 2003) and Sr (Elsdon \& Gillanders 2004) concentration in gastropod statoliths and fish otoliths respectively have been directly associated with seawater concentration, and temperature negatively correlates with $\mathrm{Sr}$ concentration in squid statoliths (Arkhipkin et al. 2004) and octopus statoliths (Ikeda et al. 1999). Food is likely to be an important source of element uptake for cephalopods, due to their rapid growth rate, high metabolism and food intake requirements (Bustamante et al. 2004), with diet found to significantly influence Ba concentrations in cuttlefish statoliths (Zumholz et al. 2006). Stylets, unlike statoliths and otoliths, which are surrounded by endolymphatic fluid (the composition of which is suggested to be under significant physiological regulation) (Campana 1999), are in direct contact with muscle tissue, and element uptake is likely to be effected by a different, and perhaps more direct, physiological pathway. Adult and juvenile cuttlefish Sepia officinalis, for instance, have been shown to rapidly incorporate Co and Ag into their muscle tissue from seawater (Bustamante et al. 2004).

The present study shows that targeted elemental analysis is a particularly useful technique for understanding population linkages in merobenthic octopuses, providing valuable information without the necessity of juvenile individuals. Traditional tagrecapture methods have proven incredibly difficult to use for marine species with planktonic young, due to the small size of larvae and juveniles, high mortality rates of offspring and the large number of animals which need to be tagged to recover sufficient sample sizes (Thorrold et al. 2001, Gillanders 2002). Further- 
more, adult octopuses are particularly difficult to tag due to their tendency to remove the tag. Molecular markers are a powerful tool for investigating population structure in octopuses, but the recent use of both elemental and molecular techniques within a single study has shown that elemental signatures do not just reproduce but also complement genetic data (see Miller et al. 2005, Ashford et al. 2006). Genetic methods provide estimates of dispersal over long timescales, with, theoretically, an exchange of only a few individuals per generation required to maintain genetic homogeneity among populations (Semmens et al. 2007). On the other hand, elemental signatures can indicate distinct subpopulations that are otherwise genetically homogeneous due to periodic low-level mixing or mixing during the early stages of the life cycle (Campana \& Thorrold 2001, Arkhipkin et al. 2004), which would be particularly common for species with planktonic young.

In summary, the present study has provided evidence of localised population structuring in the Octopus maorum population through the analysis of elemental signatures within the early life history region of stylets. As it is difficult to discern whether similar signatures between sites are due to dispersal or similar water chemistries, levels of connectivity are hard to define. Larger sample sizes, a larger number of sample locations and some understanding of the relationships between the environmental availability of elements and elemental concentrations within the stylet would improve such uncertainties. It would also be useful to conduct a similar study using a different technique, such as molecular markers, as a multi-technique approach to understanding such aspects of marine populations has been shown to provide both corroborative and complementary results (e.g. Kassahn et al. 2003, Miller et al. 2005). Our results will help determine the appropriate sustainable scale at which the $O$. maorum fishery ought to be managed. Additionally, we have shown that elemental analysis of the octopus stylet will provide a powerful tool to resolve issues of population structure and dispersal in more heavily fished octopus species.

Acknowledgements. We thank J. Ricketts, N. Perryman, W. Beven, W. Combe, D. Palmer, Moana Pacific Fisheries, South Pacific Fisheries, Burkhart Fisheries and Austar Fisheries for the collection of octopuses in Tasmania, NZ and SA, and M. Oliver (National Institue of Water and Atmosheric Research, NIWA) and D. Sykes (NZ Rock Lobster Industry Council) for overseeing the collection and storage of octopuses in NZ. We also thank S. Gilbert (CODES) for technical assistance with LA ICPMS and S. Stephens (University of Tasmania) for help preparing the epoxy mounts. This study was supported by the Holsworth Wildlife Research Endowment, Department of Primary Industries and Water (Tasmania), Winifred Violet Scott Estate grant and Unitas Malacologica.

\section{LITERATURE CITED}

Arkhipkin AI, Campana SE, Fitzgerald J, Thorrold SR (2004) Spatial and temporal variation in elemental signatures of statoliths from the Patagonian longfin squid (Loligo gahi). Can J Fish Aquat Sci 61:1212-1224

Ashford JR, Arkhipkin AI, Jones CM (2006) Can the chemistry of otolith nuclei determine the population structure of Patagonian toothfish Dissostichus eleginoides? J Fish Biol 69:708-721

Avise JC (2004) Molecular markers, natural history and evolution. Sinauer Associates Publishers, Sunderland, MA

Balguerías E, Quintero ME, Hernández-González CL (2000) The origin of the Saharan Bank cephalopod fishery. ICES J Mar Sci 57:15-23

Becker BJ, Fodrie FJ, McMillan PA, Levin LA (2005) Spatial and temporal variation in trace elemental fingerprints of mytilid mussel shells: a precursor to invertebrate larval tracking. Limnol Oceanogr 50:48-61

> Becker BJ, Levin LA, Fodrie FJ, McMillan PA (2007) Complex larval connectivity patterns among marine invertebrate populations. Proc Natl Acad Sci USA 104:3267-3272

Bizikov VA (2004) The shell in Vampyropoda (Cephalopoda): morphology, functional role and evolution. Ruthenica, Moscow

Bustamante P, Teyssie JL, Danis B, Fowler SW, Miramand P, Cotret O, Warnau M (2004) Uptake, transfer and distribution of silver and cobalt in tissues of the common cuttlefish Sepia officinalis at different stages of its life cycle. Mar Ecol Prog Ser 269:185-195

Campana S (1999) Chemistry and composition of fish otoliths: pathways, mechanisms and applications. Mar Ecol Prog Ser 188:263-297

Campana SE, Thorrold SR (2001) Otoliths, increments, and elements: keys to a comprehensive understanding of fish populations? Can J Fish Aquat Sci 58:30-38

Crawford CM, Edgar GJ, Cresswell G (2000) The Tasmanian region. In: Shepherd C, Zann LP (eds) Seas at the millennium: an environmental evaluation. Elsevier, Amsterdam, p 647-660

$>$ Dillane E, Galvin P, Coughlan J, Lipinski MR, Cross TF (2005) Genetic variation in the lesser flying squid Todaropsis eblanae (Cephalopoda, Ommastrephidae) in east Atlantic and Mediterranean waters. Mar Ecol Prog Ser 292: $225-232$

> Doubleday ZA, Semmens JM, Pecl GT, Jackson GD (2006) Assessing the validity of stylets as ageing tools in Octopus pallidus. J Exp Mar Biol Ecol 338:35-42

Doubleday Z, Belton D, Pecl G, Semmens J (2007) Quantitative elemental imaging of octopus stylets using PIXE and the nuclear microprobe. Nucl Instr Meth Phys Res B 266: $67-72$

> Elsdon TS, Gillanders BM (2004) Fish otolith chemistry influenced by exposure to multiple environmental variables. J Exp Mar Biol Ecol 313:269-284

Elsdon TS, Gillanders BM (2005) Strontium incorporation into calcified structures: separating the effects of ambient water concentration and exposure time. Mar Ecol Prog Ser 285:233-243

Farnham IM, Singh AK, Stetzenbach KJ, Johannesson KH (2002) Treatment of nondetects in multivariate analysis of groundwater geochemistry data. Chemometr Intell Lab Syst 60:265-281

> Gillanders BM (2002) Connectivity between juvenile and adult fish populations: Do adults remain near their recruitment estuaries? Mar Ecol Prog Ser 240:215-223

Gillanders BM (2005) Using elemental chemistry of fish 
otoliths to determine connectivity between estuarine and coastal habitats. Estuar Coast Shelf Sci 64:47-57

Hamer PA, Jenkins GP, Gillanders BM (2005) Chemical tags in otoliths indicate the importance of local and distant settlement areas to populations of a temperate sparid, Pagrus auratus. Can J Fish Aquat Sci 62:623-630

Ikeda Y, Nobuaki A, Sakamoto W, Mitsuhashi M, Yoshida K (1999) Preliminary report on PIXE analysis for trace elements of Octopus dofleini statoliths. Fish Sci 65:161-162

Jones BG, Chenhall BE, Debretsion F, Hutton AC (2003) Geochemical comparisons between estuaries with non-industrialised and industrialised catchments: the Huon and Derwent River estuaries, Tasmania. Aust J Earth Sci 50: 653-667

Kassahn KS, Donnellan S, Fowler SW, Hall KC, Adams M, Shaw PW (2003) Molecular and morphological analyses of the cuttlefish Sepia apama indicate a complex population structure. Mar Biol 143:947-962

Maltagliati F, Belcari P, Casu D, Casu M, Sator P, Vargiu G, Castelli A (2002) Allozyme genetic variability and gene flow in Octopus vulgaris (Cephalopoda, Octopodidae) from the Mediterranean Sea. Bull Mar Sci 71:437-486

Miller JA, Banks MA, Gomez-Uchida D, Shanks AL (2005) A comparison of population structure in black rockfish (Sebastes melanops) as determined with otolith microchemistry and microsatellite DNA. Can J Fish Aquat Sci 62:2189-2198

Murphy JM, Baguerias E, Key LN, Boyle PR (2002) Microsatellite DNA markers discriminate between two Octopus vulgaris (Cephalopoda: Octopoda) fisheries along the northwest African coast. Bull Mar Sci 71: 545-553

Oosthuizen A, Jiwaji M, Shaw P (2004) Genetic analysis of the Octopus vulgaris population on the coast of South Africa. S Afr J Sci 100:603-607

Palumbi SR (2004) Marine reserves and ocean neighbourhoods: the spatial scale of marine populations and their management. Annu Rev Environ Resour 29:31-68

Pearce NJG, Perkins WT, Westgate JA, Gorton MP, Jackson SE, Neal CL, Chenery SP (1997) A compilation of new and published major and trace element data for NIST SRM 610 and NIST SRM 612 glass reference materials. Geostandards Newl 21:115-144

Raimundo J, Caetano M, Vale C (2004) Geographical variation and partition of metals in tissues of Octopus vulgaris along the Portuguese coast. Sci Total Environ 325:71-81

Rigby PR, Sakurai Y (2005) Multidimensional tracking of

Editorial responsibility: Otto Kinne,

Oldendorf/Luhe, Germany giant Pacific octopuses in northern Japan reveals unexpected foraging behaviour. Mar Technol Soc J 39:64-67

Rocha FJ, Vega MA (2003) Overview of cephalod fisheries in Chilean waters. Fish Res 60:151-159

- Semmens JM, Pecl GT, Gillanders BM, Waluda CM and others (2007) Approaches to resolving cephalopod movement and migration patterns. Rev Fish Biol Fish 17:401-423

Smith CD, Groeneveld JC, Maharaj G (2006) The life history of the giant octopus Octopus magnificus in South African waters. Afr J Mar Sci 28:561-568

Stranks TN (1996) Biogeography of Octopus species (Cephalopoda: Octopodidae) from southeastern Australia. Am Malacol Bull 12:145-151

> Swan SC, Geffen AJ, Morales-Nin B, Gordon JDM, Shimmield T, Sawyer T, Massutí E (2006) Otolith chemistry: an aid to stock separation of Helicolenus dactylopterus (bluemouth) and Merluccius merluccius (European hake) in the Northeast Atlantic and Mediterranean. ICES J Mar Sci 63:504-513

- Teske PR, Oosthuizen A, Papadopoulos I, Barker NP (2007) Phylogeographic structure of Octopus vulgaris in South Africa revisited: identification of a second lineage near Durban harbour. Mar Biol 151:2119-2122

Thorrold SR, Latkoczy C, Swart PK, Jones CS (2001) Natal homing in a marine fish metapopulation. Science 291: 297-299

Tomczak M (1981) Bass Strait water intrusion in the Tasman Sea and mean temperature-salinty curves. Aust J Mar Freshw Sci 32:699-708

- Villanueva R, Bustamante P (2006) Composition in essential and non-essential elements of early stages of cephalopods and dietary effects on the elemental profiles of Octopus vulgaris paralarvae. Aquaculture 261:225-240

Zacherl DC (2005) Spatial and temporal variation in statolith and protoconch trace elements as natural tags to track larval dispersal. Mar Ecol Prog Ser 290:145-163

Zacherl DC, Paradis G, Lea DW (2003) Barium and strontium uptake into larval protoconchs and statoliths of the marine neogastropod Kelletia keletii. Geochim Cosmochim Acta 67:4091-4099

> Zumholz K, Hansteen TH, Klügel A, Piatkowski U (2006) Food effects on statolith composition of the common cuttlefish (Sepia officinalis). Mar Biol 150:237-244

Zumholz K, Klügel A, Hansteen T, Piatkowski U (2007) Statolith microchemistry traces the environmental history of the boreoatlantic armhook squid Gonatus fabricii. Mar Ecol Prog Ser 333:195-204

Submitted: August 1, 2007; Accepted: December 21, 2007 Proofs received from author(s): April 29, 2008 